\title{
Julia Kristeva: The Polylogic Wager (Part I)
}

\author{
Miglena Nikolchina
}

\section{Julia Kristeva: Le pari polylogique (Partie 1)}

Kristeva est probablement mieux connue pour avoir avoir reliéla pratique de l'avant-garde poétique et la figure de la mère à travers le concept de chora sémiotique. Mais Kristeva a aussi développéle problème de l'espace maternel en référence à la psychoanalyse, l'épistémologie et la métaphysique, l'anthopologie et l'histoire de l'art, de la religion et des idées politiques. Miglena Nikolchina propose que nous lisions cette oeuore profondément interdisciplinaire, entreprise dans laquelle divers discours théoriques sont stratifiés pour que l'objet puisse être appréhendé selon diverses approches distinctes, d'où la référence au polylogue, terme utilisé par Kristeva pour désigner la rencontre entre une formule de corps théorique et un texte. Le polylogue est une énonciation rythmique de la douleur, une musicalitédu langage, un renversement de la séparation des genres, pour que "toutes les cordes de ce prodigieux instrument qu'est le langage soient jouées ensemble et simultanément." Cela requier le paridu sujet stable de la théorie, que Kristeva accomplit dans son oeuvreen redoublant constamment le sujet de la théorie avec des sujets déstabilisés et précaires comme l'abject et la mélancolie. D'après Kristeva, pour prendre ce risque il est probablement nécessaire d'être une femme, consciente de l'ineptie de l'Être. Pourquoi, alors, est-ce que les critiques féministes de Kristeva (Silverman, Stanton, Butler, Rose, Grosz) ont trouvé dans sa théorie que la mère, la femme artiste, la lesbienne, et même la femme en général sont réduites au silence? Nikolchina situe la source des ces critiques dans la théorie de l'asymbolie de la fermme de Kristeva. Elle nous rappelle que l'asymbolie est le diagnostic de Kristeva sur la condition des femmes en rapport à une symbolique qui fonctionne par l'exclusion de la féminité. Elle rappelle également que cette condition d'étrangère au langage, attribuée à Virginia Woolf par Kristeva, est aussi la propre condition d'exil de Kristeva. Kristeva soutient qu'il est nécessaire de devenir une étrangère par rapport au langage pour être en mesure d'éprouver la matérialitédu langage. Le pathos des croisades contre l'asymbolie, affirme 
Nikolchina, réside dans leur volonté de sacrifier le muet et le caché, afin de pluraliser la rationalité dans le but de communiquer.

(La deuxième partie de l'essai de Nikolchina sera présentée dans le prochain numéro de Tessera.)

\section{The Quest for the Mother}

At its various stages, Julia Kristeva's theoretical writing develops the problem of maternity and the figure of the mother with reference to the conceptual frameworks of different disciplines: linguistics and poetics, psychoanalysis and semiotics, epistemology and metaphysics, anthropology and the histories of art, religion, or political ideas. "Developing" should be read here in its double meaning of elaborating a concept and of making an invisible image come through. In the latter meaning, the presumption would be that the maternal "space vis-à-vis reason" was always already there, within the functioning of the various discourses, but veiled. Camouflaged. Alluding to the classical myth of Zeus's swallowing of the goddess of wisdom Metis, one might say: swallowed.

In order to gain access to this hidden space, Kristeva's theoretical approaches turn towards other realms of signifying practices - i.e. spheres of activity that exhibit the process of the sign's becoming. In their double mode of constituting and traversing ${ }^{1}$ the system of signs, signifying practices involve the making and the unmaking of the speaking subject and its identity. Hence they require an unfinished, splitting and fragmented, multiple and dynamic "subject" in the grips of pain and jouissance, which Kristeva problematizes as a subject-in-process. Artistic practice, the situation of transference, and, least orthodoxically, the act of giving birth as the site of a split symbolization, provide their several perspectives for the always uncertain scene at the far side of signification, "whence bodies, identities, and signs are begotten" (Kristeva 1980: 269). The interdisciplinarity of Kristeva's theoretical discourse is thus unfurled via the manifold passageways broached by such practices, ranging as they do from the artistic traversing of signs to the starkness of an act as physical - but, Kristeva insists, also as coded and ciphered - as the act of parturition.

In so far as the mother is concerned, two major outcomes emerge out of this joining of theory and practice. Theoretical discourse, traversed by the signifying practices it seeks to analyze, approaches its own outer 
limits and questions its own assumptions. The execution of this corrosive questioning is designated by Kristeva as "semanalysis" - a procedure that meets the "requirement to describe the signifying phenomenon, or signifying phenomena, while analyzing, criticizing, and dissolving 'phenomenon,' 'meaning,' and 'signifier'" (1980: vii). Within this setting of theory-as-practice, the maternal space is revealed as the boundary, the difficult to recuperate outside that both delineates and challenges the rigour and the coherence of theoretical homogeneity. Confronted with the analytic venture, signifying practices, on the other hand, wield a knowledge which they do not necessarily "know" but which renders the production of meaning and of the subject transparent. Through this knowledgable transparency, the mother is recovered as the dynamic factor in both the generation and the exceeding of the signifier. For the homogenous space where meaning, syntax, and logic hold sway, the mother is the outside that sustains it and exposes its limitations; within the heterogeneous space where signs are produced and dissolved, the mother is the dialectic that generates and shatters them.

In this way, across Kristeva's theory, a pervasive narrative, a fiction, or, to activate the ambiguity of the French word histoire, a history and a tale surfaces - the history and the tale of the mother, of her absence (for she is always outside of syntax and logic) and of her power (for she is their constitutive and productive outside). This, moreover, is a history and a tale of great pathos for it tells of the precautious loss (of the mother), of the pains, the fears and the longings brought about by the separation (from the mother), and of the disconsolate wanderings (in search of the mother) of the speaking being, an exile prone to despondency and exaltations, and destined to traverse the forever foreign country of other languages and metalanguages that promise a reunion (with the mother), yet deviate further and further away from her in a perpetual "polytopic" quest. ${ }^{2}$

And this is not all. For if the disjunction between the homogeneous and synchronic space where theoretical codes function and the heterogeneous and diachronic space where they come into being gives rise to the fiction of the powerful but lost mother, there is also a mode in which synchrony and diachrony become coextensive and heterogeneity is set forth as part of the symbolic homogeneity itself-a transversal, wayward part, to be sure, that makes the absent mother in effect always present. This problematic presence crisscrossing the linearity of the symbolic as 
the order of the sign, of syntax, and of the law, is what Kristeva designates as the "semiotic chora." 3 Although a precondition of the symbolic in terms of its histoire, although a sequence of the symbolic in terms of its organization into an observable device, the semiotic chora is always simultaneous with it as the symbolic's shaking and transgression: an excess that makes language sing and explodes light into colour. Most evident in avant-garde poetic practice, the semiotic is nevertheless inhabiting - and inhabited by - any functioning of language and the symbolic. It thus presents a constant challenge to temporal distinctions through the paradox of a past that never passes and that finds its reiteration as rhythm and laughter.

Kristeva's work, therefore, brings the maternal, first, into theory through the rewriting of certain most perplexing concepts that are "apprehended through difficult reasoning"4 (the chora of Plato's ontology, the Negativität and Kraft of Hegel's dialectic), and through the persistent unsettling of the subject-object dichotomy by other, less distinct and more disquieting divisions (the abject of the ... abject, where the very necessity to name in one and the same way the "subject" and the "object" of abjection indicates the uncertainty of the division; the thing of the melancholic; as well as their luminous correlative in the jouissance of the mystic and the artist). Second, across this theoretic rehabilitation of the mother the tale/history of her loss emerges as the presiding destiny of the speaking being, forever mournful and therefore creative. And finally (in the logical order that I propose and not in the chronology of Kristeva's biography as an author), the semiotic smuggles in the mother as a transversality to both theory and fiction, shaking and pulverizing meanings when it is not actually shattering and producing them: as the rhythm and the exorbitance of sound in language, as the excess of colour in painting, as the very principle of music or dance, and in all that as the nonsignifiable articulation of jouissance and death.

\section{The Theoretical Subject}

To demonstrate that Kristeva's theoretical writing does not simply lay out all these maternal aspects of the destiny of the speaking being, but that it involves them in a signifying practice, is to answer the question about the subject of theory as an unalienable and indispensable dimension of the theory that purports to take into account the crises of mean- 
ing, subject, and structure. Kristeva's notion of the "epistemologic device" insists on the interrelation between the subject of theory and its object. What is the epistemologic device of Kristeva's theory? Is there a theoretical subject-in-process across the theory of the subject-in-process, presented in Revolution in Poetic Language? Is the theoretician of abjection in Powers of Horror a precarious subject haunted by a ghostly glimmer? Is the study of melancholy in Black Sun the painful enunciation of a melancholic theoretician? Is Kristeva's theoretician stratified across the heterogeneous polytopical space of the signifying processes that she studies? Is this theoretician a "subject in infinite analysis" (1980: 146)? Can theory be a text and is it possible to adopt a perspective in which Kristeva's theoretical writing is a text? Sometimes explicitly, but in all cases by its operations, Kristeva's writing makes us face these questions: not simply in the version of unmasking the impostures of theory, but rather, as a requirement that we take into account the subject of theory as part of the theory itself.

The answer to these questions will determine the possibility of describing Kristeva's work as possessing an epistemological device in which the subject of theory traverses its sutures of foreclosure via various signifying practices. To use another of Kristeva's coinages, this is to determine the possibility of describing her work as a polylogue. The term, so rich in connotations (is it a multiplication of the Platonic Logos? of the Aristotelian Logic? of the Lacanian Signifier? of the Bakhtinian Dialogue? or, to put it the other way round, is it a transposition of the Bakhtinian polyphonic novel into theory?), is introduced as the title to one of Kristeva's books. The very manner in which the term is unravelled hereafter is indicative. In the Preface to the book, the polylogue is defined with theory as its starting point. It is presented as a multiplication of rationality, clearly relying on an interdisciplinary endeavour, and as a transposition of the One into various registers, i.e. as a procedure that requires the positing, each time, of a unique subject, and appeals to the inimitable and the irretrievable. In this perspective, the polylogue is postulated as the stratification of logic in singular accounts, resulting from the semanalytic invocation of the unnamable. It thus might be seen as a movement of theory towards ... the novel.

From within the book, however, from one of its essays, entitled "The Novel as a Polylogue," the term emerges in the redoubling, typical of Kristeva's writing, of the quest of a female theoretician with the signifying practice of a male artist (I shall return to that). A novel-as-text 
encounters an embodied subject of theory and the resulting clash enacts the polylogue no longer as a multiple splitting of logic and discourse, but ultimately as a shattering of the body in the rhythmic enunciation of "a pain that severs the "'self,' the body, and each organ" (1980: 184). The agent of this "multiple schiztic pain" is introduced as, paradoxically, a musicating of language, as an ability to hold all the timbres of enunciation together, and, finally, as a reversal of the breaking up of genres, so that "all the strings of this prodigious instrument that language is are played together and simultaneously" (1980: 174). What "descends" (from the conceptual heaven of theory) as a multiplication of the one logic in a movement towards uniqueness and singularity, "ascends" (from within artistic practice) as the reunification of literary genres: they collide in the "precise jouissance" of a body/text.

The result of this collision (of theory and artistic practice, of precision and jouissance, of semiotic and symbolic operations) is not a kind of new synthetic fusion or totality (of genres or disciplines), but a "nonsynthetic joining." ${ }^{5}$ A concurrent non-synthesis of logic and pain. Distinct but simultaneous. Separate but coextensive. Engaged in a multiple disjunctive dialogism. Sustained by an asymmetrically split heteronomous subject. It is important that we do not mistake the polylogue, the genus of a theory conscious of its narrative and semiotic dimensions, for a parable that exhausts the domain of the subject. As the genre mindful of the subject's hazards and rebirths, the polylogue, a space that Kristeva situates later on within the exemplary open-ended structures of analytic love, can be entered (through curiosity or pain) and exited (through the effective cure). Hence it has an outsidecontaining the possibilities of the subject's utter annihilation as well as its utopian health. The polylogue articulates the mean between annihilation and health, pointing towards utopia yet always returning to the problematic site that makes utopia necessary.

Within these boundaries, the polylogue sounds the registers partaking of the mother - from the semanalytic exploration of the "outer borders of the signifying venture of man" (1980: $x$ ) that formulates new tasks for theory to the somatic shattering and jubilation. It is probably necessary to be a woman, Kristeva adds, "aware as she is of the inanity of Being" (1980: 146), in order to admit the subject of theory as a subject in infinite analysis, and to take up an exorbitant wager. The wager that will endow us, not with a resurrection, but with multiple rebirths from the deluge of the drives, and that will teach us to tolerate "multiple logics, 
speeches and existences" (1977: 9). What gives meaning to the intellectual risks of the polylogic project is, ultimately, the effective recognition of otherness as the formulation of a new basis for communication and togetherness.

Should we, then, read Kristeva's oeuvre as a polylogue?

\section{Kristeva's Feminist Critics}

The fact that Kristeva writes about motherhood has drawn a lot of attention; what has often been ignored is the fact that the shifting reconceptualization of the mother across a variety of heterogeneous discourses introduces the maternal problematic as a vantage point for the critique of these discourses and, at the same time, asserts this problematic as a moment of their (to use Benjamin's term) refunctioning. Many of the various critiques of Kristeva converge in their belief that her theory has a disarticulating effect. There has been little agreement, however, as to whom her theory disarticulates. According to one group of opinions, Kristeva's theory disarticulates the mother either by projecting the muteness of the infant on her, as Kaja Silverman believes, or by sacrificing her to the exigencies of theory: "the discourse of maternity gives birth to Kristevan poetics" (Jacobus). ${ }^{6}$ According to another group of opinions, represented by Domna Stanton, by focusing on the dyad mother/male artist, Kristeva reinforces the prevalent privileging of male artists and disarticulates the woman artist. Yet another group of critics maintains that, by refusing to set up the semiotic - no longer seen in a reductive light - as an alternative to the symbolic and female libido as an alternative to the male one, Kristeva "designates female homosexuality as a culturally unintelligible practice, inherently psychotic" (Butler). ${ }^{7}$ And finally, it is argued that the disarticulation applies to woman in general: the chora is believed (by Jacqueline Rose) to smuggle directly its platonic reduction of the feminine to a container without any inherent relation to the generation of the offspring. Or rather, as a structural manifestation of the failure of Kristeva to transcend Lacan, the chora and the semiotic remain, according to Elizabeth Grosz, beyond woman's grasp because of woman's asymbolia. ${ }^{8}$

This study will try to address these objections and, perhaps, provide some answers. For, if the critiques are indeed grounded in Kristeva's work, they make us ultimately face the question from what position Kristeva herself is able to speak. How are we to relate Kristeva's views of 
female asymbolia - which she does hold - to her belief that perhaps a woman is necessary to take up the exorbitant wager of carrying the rational project to the outer borders of the signifying venture of men? How can her ideas of woman as asymbolic singularity be reconciled with the persistent Kristevan theme of woman's eternal exile as a possible vantage point for a polylogic rebirth of meaning? Is there a passage or transitional procedure from the asymbolia to the exorbitant wager? If Kristeva utterly disarticulates women as spastic, asymbolic bodies, then how can she expect a woman to take up the wager of the polylogue?

\section{Asymbolia}

"Fear of the archaic mother turns out to be essentially fear of her generative power. It is this power, a dreaded one, that patrilineal filiation has the burden of subduing." (Kristeva 1982:77) "Phallic power, in the sense of a symbolic power that thwarts the traps of penial performance, would in short begin with an appropriation of archaic maternal power." (Kristeva 1987: 75) "Phallic idealization is built upon the pedestal of a putting-to-death of the feminine body." (Kristeva 1987: 357)

The "murder" of the feminine body - its evacuation from an idealization that is always already phallic - founds woman's asymbolia. Asymbolia is the condition of woman with regard to a symbolic that functions through the exclusion of femininity. According to Kristeva's account in the untranslated sections of Revolution in Poetic Language, this condition is effected through a complicity between the "state" and "mystery," which guarantees the disjunction between production and reproduction and occludes genitality. In this way, the symbolic may afford to remain ignorant of sexual difference, and mystery may practice it under the condition that it does not know it.

The emphasis on mystery as the reverse, hidden side of the law, as the preserve of femininity, jouissance, and death, displaces the emphasis of Lévi-Strauss's approach that, Kristeva believes, tends to neglect heterogeneity or to treat it as a depository of laws. According to Kristeva, LéviStrauss's anthropological vision brackets the mother-child relationship. Her study of mystery extends her mostly oblique but massive critique of the bracketing that sustains Lévi-Strauss's structures. As the unspoken double of the social code, mystery creates an alternative economy enclosing the residues of a symbolic that, in Lévi-Strauss's account, treats women as objects of exchange. Yet as the double of the symbolic, 
as the representation of heterogeneity for the symbolic, mystery also makes the efficiency of the code impeccable. Mystery submits heterogeneity to the exigencies of the law (this submission corresponds to the phallicization of the mother) and arrests the possibilities for structural change.

Within this arrangement, femininity, therefore, harbours the mystery and has no outlet into the symbolic. The eternal feminist movement of the suffragists, Kristeva contends, is in search of understanding woman's spastic force, which is presented as castration by the phallic culture, but this force cannot find its proper representation and cannot be absorbed by the paranoid logic of the phratry that is offered to it. Two paths are open to woman: to find her specificity in a kind of asymbolic singularity, or to live in disguise, pretending that she observes the law that neither sees, nor signifies her. (Kristeva 1977: 78-79)

"In woman's writing, language seems to be seen from a foreign land," Kristeva states in a much debated passage, "is it seen from the point of view of an asymbolic, spastic body?" In a phrase that revives the drama of Andersen's Little Mermaid who dreams of the foreign land, the drama of a longing that has no tongue and that finds its expression in the piercing pain of separation (a separation from the sea-sisters and a separation of the body for swimming into a body for walking), Kristeva speaks of women as "visionaries, dancers who suffer as they speak." (1981: 166).

The disturbing poignancy of the passage does not come so much from its Little Mermaid pathos but rather from its example: Virginia Woolf, a writer who seems to have been as close to becoming the voice of the Zeitgeist as a woman has ever been able to, and who has been persistently dislocated from that position. Did this dislocation come about because of asymbolia? Because Woolf - as Kristeva puts it - "does not dissect language as Joyce does (1981: 166)?"

\section{Asymbolia as a Gratuity}

It is worth keeping in mind the fact that Woolf's position, as described by Kristeva, redoubles her own, and that, within Kristeva's settings, asymbolia is not entirely a drawback. First of all, asymbolia as a foreignness to language - the way Woolf is envisioned as seeing language from a foreign land -is inscribed within Kristeva's persistent concern with exile and foreignness (étrangeté). After the exotic title of her first book in 
French, Kristeva, who was presented to the French reading public by Roland Barthes as l'étrangère, proceeds with an observation on the necessity to be or to become a foreigner to language in order to make it worklabour - and to confront it as materiality. To emphasize her point, Kristeva adds a foreign word - foreign to the medium of her text which in its entirety is foreign to her as the étrangère author. In order to $\pi 0 \lambda \varepsilon \hat{\imath} V$ and if we decipher this $\pi 0 \lambda \varepsilon \hat{\imath} v$, silently appealing to the beginnings of the Occident, via a Bulgarian ear, its voicing will come close to "sing," a meaning certainly not at odds with the Greek expanse of the word - in order to $\pi \mathrm{o} \lambda \varepsilon \hat{\imath} v$, that is, to make language work and sing, we have to turn ourselves into "strangers to language" (Kristeva 1969: 9). We have to stop understanding it and look at it from the position of a radical incomprehension - we have to become language's other. In Kristeva's later work, this strangeness to language is problematized through the position of the melancholic, fused with the maternal Thing of an unaccomplished separation from the mother. Asymbolia, then, is the (insufficiently) lost maternal continent, the invisible centre of gravity, the hidden image of Narcissus, whose silent call threatens with dissolution. But, on the other hand, without an ear for that silence and without the estrangement from language that prods the melancholic on a quest for the totally new word, there can be no psychic life or imagination, and, ultimately, as Kristeva argues in Strangers to Ourselves, there can be no basis for understanding and cooperation, no hope for the paradoxical universality demanded by a world without boundaries. Woman's asymbolia, therefore, and Woolf's speaking with the difficulty of a visionary and a dancer, with the painful force of a spastic body, might not be as disparagingly and hopelessly presented by Kristeva as some of her commentators have taken it to be.

The estrangement of asymbolia might, in fact, be a fitting beginning for the singing work of language. Kristeva's theoretical preoccupation with what is excluded, with the outside of discourse-a preoccupation that overlaps more or less with the topology of the lost mother - is another instance that specifies her perspective on asymbolia. In so far as she is asymbolic, woman inhabits that place where unique incommunicable "meanings" hold sway. Wavering between masquerade and asymbolic singularity, she encompasses the modern choice between a theatrical, ludic subjectivity (the $j e$ of $j e u$ ) and a problematic, unexchangeable uniqueness. It is true that the valorization of unique reports 
undermines the importance of communication and exchange: in Kristeva's early writing, the productivity of language is emphatically set against its communicative aspect. Although the polylogue promises the generality of a logic and, in the long run, the hope for a community of strangers, its emphasis is still on "marking the existence of a life" rather than on making the life communicable. We might argue to what extent Kristeva's later interest in transference as the secret of being psychologically alive and her interest in the modern soul as an open system revises this emphasis; horror, love, melancholy, and the strangeness to ourselves that Kristeva's later works deal with seem to share the feature of being, properly speaking, incommunicable, even amidst the promised community of strangers. Only in infinity will the lovers meet; the transferential relationship, this modern love story, is not an encounter, not an attainment of the other, but a technique for opening the psychic space towards a playful expansion, towards a vibrant balancing upon the razor's edge of a world where certainties, final answers, and dogmas are no longer possible. There are, accordingly, signs, throughout Kristeva's oeuvre, hinting that whatever is offered as writing is always the neti, neti- "not this, not this" - of the Upanishads. Writing is a creative opening on this side, that comes from a wandering on the far side, from a secret concern with a hidden face, a silent sister. Any crusade against asymbolia has to be aware, therefore, that its pathos comes from a valorization of communication and exchange and involves a sacrifice of the silent and the hidden.

In Kristeva's own terms, there are, in other words, things to be said in favour of the distance that separates Kristeva's Woolf from the "foreign" language. Rendering the generality of logic to singular reports, the possibility for a subtilization of the superego will come from the silence and the concealment, from the obscure continent of femininity. The multiplication of rationality is achieved through the movement towards the unnamable (towards primary repression, the unknown of mystery, genitality, the mother). As with H.D.'s Helen who gazes, across death and jouissance, into the sea-enchantment of Achilles's eyes, and invokes the name of Thetis, Kristeva's invocation to the mother turns the murderous clutch of a genderless language into a process where sexual differentiation is effected. Such is the polylogic wager offered to asymbolic singularity.

It is to the theoretical conditions of this analysis that we turn now. 


\section{Not This}

How can theory posit an object that is beyond its limits? How can it make an "object" out of that which departs from meaning? "By positing itself as nonuniversal," runs one of Kristeva's answers,

that is, by presupposing that a questionable subject-in-process exists in an economy of discourse other than that of thetic consciousness. And this requires that subjects of the theory must be themselves subjects in infinite analysis ... (Kristeva 1980: 146)

This confrontation between the subject of theory and the subject of a heterogeneous economy gives rise to a sort of enactment of the "sliding" of the theoretical signifier that sets off the nonuniversality of theoretical discourses. This technique is most clearly exemplified in the method of Revolution in Poetic Language which consecutively proceeds through general theories of meaning, theories of language, and theories of the subject in order to demonstrate their indispensability and inadequacy for describing the object of Kristeva's inquiry. The method has been defined as montage, but it would be far more precise to describe it as a stratification of the theoretical discourse in a manner that resists one-dimensional filiations and loyalties and approaches its object via a number of distinct routes. This multigenealogy continues to show through the anchoring of Kristeva's subsequent writing in psychoanalysis whose privileged theoretical position seems to derive ultimately from a gesture that points outside theory towards an understanding of truth as the capacity for renovation and rebirth.

The stratification of theoretical discourse is, therefore, an answer to the problem of signification that questions the (symbolic) foundations of universality. ${ }^{9}$ Another answer is the "subject of a heterogeneous economy" which has proved to have numerous topoi as well. In her early work Kristeva posits the necessity for a nonreductive typology of semiotic practices. Later on this necessity is exemplified by an open series of inquiries into a variety of subjective positions that allow glimpses of the unspeakable: inquiries into what she terms "diverse modalities of access" to the symbolic function. A double star of a sort is thus formed in which an emptiness or irrevocable silence is accosted through the "rays" of various theoretical concepts (Heraclitus's matter that is always already split, Plato's chora, Hegel's negativity, Freud's death drive, etc.). 
This advance from the point of view of the theoretical subject, with all the difficulties that its position imposes on pursuits of this kind, is then mediated through a second "star" of various destabilized, precarious subjects within a field edged by poetry and madness: the abject in Powers of Horror, the melancholic in Black Sun, the sequence of forlorn or ecstatic lovers in Tales of Love. The redoubling of the subject, characteristic of Kristeva's work, is thus part of her project. Through this redoubling of the theoretical subject with the various subjects of a heterogeneous economy, the concept achieved through the "difficult reasoning" of the philosophers becomes the abject, the thing, the lost territory, the fons amoris, ecstasy, jouissance. The vide central. Not this. For we cannot enunciate this constitutive absence from which our horror and bliss spring; what we can do is, by invoking the abyss, by "wandering at the limits of the thinkable," subtilize the superego and our concepts of rationality.

\section{Notes}

1 The conceptual rigour of Kristeva's use of traverser and transversal has been lost in the various English translations. The terms imply a movement "cutting across," "crisscrossing," "vertically intersecting," and hence pulverizing, unsettling, and exhibiting, in terms of its genesis, the linear unity of the symbolic. See Kristeva's "Pratique signifiante et mode de production" in La Traversée des signes.

2 For a further discussion of this story, see Nikolchina (1991).

3 The chora is frequently described as semiotic but it is also referred to as "semiotizable." Does this mean that the chora is not necessarily semiotic?

The chora is a term borrowed from Plato. It stands for a type of concepts which posit an outside of naming, apprehended only through "difficult reasoning": to name the unnameable is to lose it (as the unnameable), yet there is no way of speaking about it outside of this naming. Hence the paradox presented by the chora: it is lost as soon as it is posited yet it is non-existent without this positing.

Kristeva's point, however, is that apart from being named and posited in theoretical investigations, the chora can be signified outside of meaning and referentiality through a certain excess in literature and the arts. This signification, an ordering outside of meaning, is an archaic maternal tongue: echolalic, vocalizing, rhythmic, etc. The chora as rendered through this maternal tongue is the semiotic. What traverses and pulverizes the symbolic is hence the semiotization of the chora: the chora's eternal return as a semiotic chora. 
The chora's return constitutes the semiotic as the space of the making and unmaking of the subject but also of the object: the semiotic signifies the formation of the subject and of the object through the stages of their problematic and uncertain separation (hence Kristeva's concepts of the abject, the Thing and other theoretical descriptions of the permeability of the subject-object dichotomy).

4 I.e. lost as soon as they are posited but nonexistent without this positing. See Kristeva, 1984: 32.

5 Kristeva applies this description to the "paragrammatic" or "intertextual" reading of two simultaneous but distinct utterances (1969: 195), as well as to the "complementary opposition" of the two different authorial personae in Lautréamont's writing (1984: 220).

6 Jacobus's observation is correct but in a broader sense: according to Kristeva, all our discourses are renovated - given birth to - through an attempt to "translate" the mother.

7 Judith Butler's later book Bodies that Matter (1993) seems to contain a tacit reevaluation of Kristeva.

8 Part of the problem seems to come from a prevalent attitude to writing as the hoarding of ammunition to blast off chosen targets. Is this writing useful? Which parts of this writing are useful? Shall we sort out the useful from the not-that-useful? Thus the big slicing of theories and authors begins: the useful Lacan, the useful Foucault, and the useful Kristeva. This procedure mars even Kelly Oliver's Reading Kristeva (1993), certainly the best American study of Kristeva so far.

9 As already mentioned, Kristeva addresses the problem of universality via "strangeness," i.e. via what is asymbolic and incommunicable.

\section{Works Cited}

Bollack, Jean and Heinz Wismann. Héraclite ou la séparation. Paris: Minuit, 1972.

Butler, Judith. Gender Trouble: Feminism and the Subversion of Identity. New York: Routledge, 1990.

- Bodies that Matter: On the Discursive Limits of "Sex". New York: Routledge, 1993.

Grosz, Elizabeth. Sexual Subversions: Three French Feminists. Sydney: Allen and Unwin, 1989.

Heidegger, Martin. Nietzsche.Volume II: The Eternal Recurrence of the Same. Trans. D. F. Krell. San Francisco: Harper and Row, 1984. 
Jacobus, Mary. Reading Woman: Essays in Feminist Criticism. New York: Columbia UP, 1986.

Kirk, G.S. Heraclitus: The Cosmic Fragments. Cambridge: Cambridge UP, 1954.

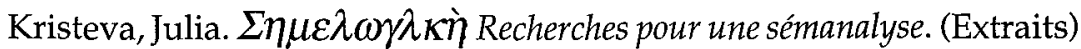
Paris: Seuil, 1969.

- La Révolution du langage poétique: l'avant-garde à la fin du XIXe siècle, Lautréamont et Mallarmé. Paris: Seuil, 1974.

_-_et al. La Traversée des signes. Paris: Seuil, 1975.

- Polylogue. Paris: Seuil, 1977.

- Desire in Language: A Semiotic Approach to Literature and Art. Trans.

T. Gora, A. Jardine, and L.S. Roudiez. New York: Columbia UP, 1980.

_. "Oscillation between Power and Denial." New French Feminisms. Eds. E. Marks and I. de Courtivron, 165-167. New York: Schocken Books, 1981.

- Powers of Horror: An Essay on Abjection. Trans. L.S.Roudiez. New York: Columbia UP, 1982.

_. "Within the Microcosm of "The Talking Cure.'" Interpreting Lacan. Eds. J. H. Smith and W. Kerrigan. New Haven and London: Yale UP, 1983.

- Revolution in Poetic Language, trans. by M. Waller. New York:

Columbia UP, 1984.

- About Chinese Women. Trans. A. Barrows. New York-London:

Marion Boyars, 1986.

—. Tales of Love. Trans. L.S.Roudiez. New York: Columbia UP, 1987.

—. Black Sun: Depression and Melancholia. Trans. L.S.Roudiez. New York: Columbia UP, 1989.

Levy, Steven. Artificial Life: The Quest for a New Creation. New York:

Pantheon Books, 1992.

Nikolchina, Miglena. "The lost territory: Parables of exile in Julia

Kristeva," Semiotica 86-3/4,(1991):231-246.

Oliver, Kelly. Reading Kristeva: Unraveling the Double-bind.

Bloomington: Indiana UP, 1993.

Rajan, Tilottama. "Trans-Positions of Difference: Kristeva and Post-

Structuralism." (manuscript, 1992).

Ricoeur, Paul. Freud and Philosophy: An Essay on Interpretation. New

Haven and London: Yale UP, 1970. 
Robinson, T.M. Heraclitus: Fragments. Toronto: University of Toronto Press, 1987.

Rose, Jacqueline. Sexuality in the Field of Vision. London: Verso, 1986.

Silverman, Kaja. The Acoustic Mirror: The Female Voice in Psychoanalysis and Film. Bloomington: Indiana UP, 1988.

Stanton, Domna. "Difference on Trial: A Critique of the Maternal Metaphor in Cixous, Irigaray, and Kristeva." The Poetics of Gender. Trans. C. G. Heilbrun and N. K. Miller. New York: Columbia UP, 1986:157-82. 